Article

\title{
Design, Synthesis, and Biological Evaluation of Pyridazinones Containing the (2-Fluorophenyl) Piperazine Moiety as Selective MAO-B Inhibitors
}

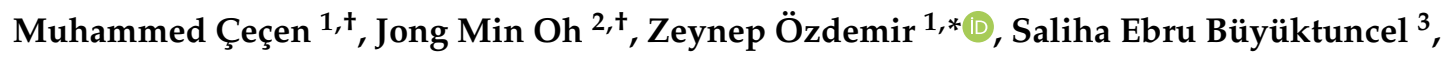 \\ Mehtap Uysal ${ }^{4}$, Mohamed A. Abdelgawad ${ }^{5,6}$, Arafa Musa ${ }^{7,8}$, Nicola Gambacorta ${ }^{9}$, \\ Orazio Nicolotti ${ }^{9}$ D, Bijo Mathew ${ }^{10, *}$ and Hoon Kim $^{2, *(D)}$ \\ 1 Department of Pharmaceutical Chemistry, Faculty of Pharmacy, Inonu University, Malatya 44280, Turkey; \\ mcecen2344@gmail.com \\ 2 Department of Pharmacy, and Research Institute of Life Pharmaceutical Sciences, \\ Sunchon National University, Suncheon 57922, Korea; ddazzo005@naver.com \\ 3 Department of Analytical Chemistry, Faculty of Pharmacy, Inonu University, Malatya 44280, Turkey; \\ saliha.buyuktuncel@inonu.edu.tr \\ 4 Department of Pharmaceutical Chemistry, Faculty of Pharmacy, Gazi University, Ankara 06100, Turkey; \\ mgokce99@gmail.com \\ 5 Department of Pharmaceutical Chemistry, College of Pharmacy, Jouf University, \\ Sakaka 72341, Al Jouf, Saudi Arabia; mohamedabdelwahab976@yahoo.com \\ 6 Department of Pharmaceutical Organic Chemistry, Faculty of Pharmacy, Beni-Suef University, \\ Beni Suef 62514, Egypt \\ 7 Department of Pharmacognosy, College of Pharmacy, Jouf University, Sakaka 72341, Al Jouf, Saudi Arabia; \\ akmusa@ju.edu.sa \\ 8 Department of Pharmacognosy, Faculty of Pharmacy, Al-Azhar University, Cairo 11371, Egypt \\ 9 Dipartimento di Farmacia-Scienze del Farmaco, Università degli Studi di Bari “Aldo Moro", Via E. \\ Orabona, 4, I-70125 Bari, Italy; nicola.gambacorta1@uniba.it (N.G.); orazio.nicolotti@uniba.it (O.N.) \\ 10 Department of Pharmaceutical Chemistry, Amrita School of Pharmacy, Amrita Vishwa Vidyapeetham, \\ Amrita Health Science Campus, Kochi 682 041, India \\ * Correspondence: zeynep.bulut@inonu.edu.tr (Z.Ö.); \\ bijovilaventgu@gmail.com or bijomathew@aims.amrita.edu (B.M.); \\ hoon@sunchon.ac.kr or hoon@scnu.ac.kr (H.K.) \\ + These authors contributed equally to this work.
}

Academic Editor: Barbara De Filippis and Gunter Peter Eckert

Received: 30 October 2020; Accepted: 13 November 2020; Published: 17 November 2020

\begin{abstract}
Twelve pyridazinones (T1-T12) containing the (2-fluorophenyl) piperazine moiety were designed, synthesized, and evaluated for monoamine oxidase (MAO) -A and -B inhibitory activities. T6 was found to be the most potent MAO-B inhibitor with an $\mathrm{IC}_{50}$ value of $0.013 \mu \mathrm{M}$, followed by T3 $\left(\mathrm{IC}_{50}=0.039 \mu \mathrm{M}\right)$. Inhibitory potency for MAO-B was more enhanced by meta bromo substitution (T6) than by para bromo substitution (T7). For para substitution, inhibitory potencies for MAO-B were as follows: $-\mathrm{Cl}(\mathrm{T} 3)>-\mathrm{N}\left(\mathrm{CH}_{3}\right)_{2}(\mathrm{~T} 12)>-\mathrm{OCH}_{3}(\mathrm{~T} 9)>\mathrm{Br}(\mathrm{T} 7)>\mathrm{F}(\mathrm{T} 5)>-\mathrm{CH}_{3}(\mathrm{~T} 11)>-\mathrm{H}(\mathrm{T} 1)$. T6 and T3 efficiently inhibited MAO-A with $\mathrm{IC}_{50}$ values of 1.57 and $4.19 \mu \mathrm{M}$ and had the highest selectivity indices (SIs) for MAO-B (120.8 and 107.4, respectively). T3 and T6 were found to be reversible and competitive inhibitors of MAO-B with $\mathrm{K}_{\mathrm{i}}$ values of 0.014 and 0.0071 , respectively. Moreover, T6 was less toxic to healthy fibroblast cells (L929) than T3. Molecular docking simulations with MAO binding sites returned higher docking scores for T6 and T3 with MAO-B than with MAO-A. These results suggest that T3 and T6 are selective, reversible, and competitive inhibitors of MAO-B and should be considered lead candidates for the treatment of neurodegenerative disorders like Alzheimer's disease.
\end{abstract}

Keywords: monoamine oxidase; pyridazinone; kinetics; reversibility; ADME; molecular docking 


\section{Introduction}

Alzheimer's disease (AD) is a fatal neurodegenerative disease characterized by progressive cognitive dysfunctions, an inability to perform daily activities, and by the various neuropsychiatric symptoms of late-stage $\mathrm{AD}$ [1]. AD is also associated with a reduction in the number of neurons in the limbic system, which manages memory processes [2]. Furthermore, the levels of many neurotransmitters, especially acetylcholine, are diminished in cerebral cortex in concert with neuronal loss, and the levels of other neurotransmitters, such as cholinergic, noncholinergic, serotonergic, dopaminergic, and neuropeptidergic neurotransmitters are altered in $\mathrm{AD}$ [3].

It has been reported that monoamine oxidase- $\mathrm{B}(\mathrm{MAO}-\mathrm{B})$ activity is enhanced in $\mathrm{AD}$, particularly in reactive astrocytes near $\beta$-amyloid $(A \beta)$ plaques [4]. In a more recent study, it was reported that the MAO-B levels were elevated in astrocytes and in pyramidal neurons in the frontal cortex, hippocampus CA1 region, and entorhinal cortex [5]. MAO-B inhibitors can reduce neuronal damage by inhibiting oxidative deamination, and it is believed that MAO-B inhibition reduces oxidative stress and neurodegeneration, and thereby, delays AD progression [6-8]. Many scaffolds, such as chalcones, chromones, coumarins, thiazolidinones, isatins, and pyrazolines, have been reported to inhibit MAO-B selectively and to exhibit promising neuroprotective properties [9-22]. In addition, MAO-B inhibitors have been recently designed with two aryl or heteroaryl hydrophobic rings separated by short enamide, unsaturated ketone, multi-conjugated ketone, amides, or hydrazone spacers [23-27].

Pyridazinones are pyridazine-containing heterocycles with two adjacent ring nitrogen atoms and keto functionality. Several FDA-approved drugs with a pyridazinone nucleus, such as pimobendan, bemoradan, indolidan, and levosimendan, have been commercialized over the past 30 years as antihypertensive, and azanrinone and emorfazone are now marketed as cardiotonic and anti-inflammatory agents, respectively [28]. Recently, our group explored a novel class of pyridazinone hydrazides with pendant piperazine moieties and investigated their abilities to competitively and reversibly inhibit MAO-B [29].

Here, we report the MAO-A and MAO-B inhibitory effects of a series of novel hydrazone derivatives (T1-T12) bearing a phenyl ring with different substituents. We previously reported the anticancer activities of seven of these derivatives (T1-T7) [30]. The other five (T8-T12) were synthesized during the present study. Lead compounds were further examined by investigating enzyme inhibition kinetics, reversibility and cytotoxicity to normal cell lines. In addition, binding modes to MAO-A and MAO-B and interactions with their active sites were determined by molecular docking simulations. Structure-activity relationships were investigated by comparing in vitro enzyme inhibition and molecular docking results.

\section{Results and Discussion}

\subsection{Chemistry}

The synthetic routes used to produce the 12 derivatives are shown in Scheme 1. Compounds were synthesized by reacting commercial 3,6-dichloropyridazine with (2-fluorophenyl)piperazine in ethanol to afford 3-chloro-6-[4-(2-fluorophenyl)piperazine-1-yl]pyridazine. The physical and spectral properties of 3-chloro-6-[4-(2-fluorophenyl)piperazine-1-yl]pyridazine concurred with literature data [30]. Compound 6-(4-(2-fluorophenyl)piperazine-1-yl)-3(2H)-pyridazinone was obtained by hydrolyzing 3-chloro-6-substituted pyridazine in hot glacial acetic acid. Ethyl 6-(4-(2-fluorophenyl)piperazine-1-yl)$3(2 \mathrm{H})$-pyridazinone-2-yl-acetate was obtained by reacting 6-(4-(2-fluorophenyl)piperazine-1-yl)-3(2H)pyridazinone with ethyl bromoacetate in acetone in the presence of $\mathrm{K}_{2} \mathrm{CO}_{3}$. Then, 6-(4-(2-fluorophenyl) piperazine-1-yl)-3(2H)-pyridazinone-2-yl-acetohydrazide was synthesized by condensing ethyl 6-(4-(2-fluorophenyl)piperazine-1-yl)-3(2H)-pyridazinone-2-yl-acetate with hydrazine hydrate (yield 99\%). The title compounds T1-T7, which contain benzalhydrazone, were obtained by condensing 6-(4-(2-fluorophenyl)piperazine-1-yl)-3(2H)-pyridazinone-2-yl-acetohydrazide with substituted/non-substituted benzaldehydes, as we previously described [31]. The other five compounds (T8-12) were synthesized 
using the same methods and are reported for the first time. The molecular structures of these compounds were confirmed by ${ }^{1} \mathrm{H}-\mathrm{NMR},{ }^{13} \mathrm{C}-\mathrm{NMR}$, and HRMS (Supplementary Materials). The molecular structures, yields, melting points, molecular weights, and molecular formulas of T1-T12 are provided in Table 1.<smiles>CC(C)(C)C(C)(C)C(F)(F)c1ccc(N2CCN(c3ccccc3F)CC2)nn1</smiles><smiles>CC#CC#CC</smiles>

(2)

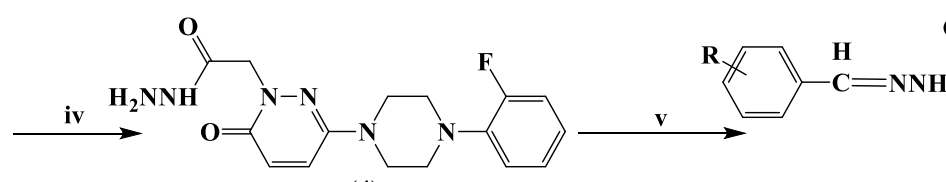

(4)
(3)

(i) EtOH, reflux (6h); (ii) AcOH, reflux (6h); (iii) $\mathrm{BrCH}_{2} \mathrm{COOCH}_{2} \mathrm{CH}_{3}, \mathrm{~K}_{2} \mathrm{CO}_{3}$, aceton, reflux (24h); (iv) $\mathrm{H}_{2} \mathrm{NNH}_{2} \cdot \mathrm{H}_{2} \mathrm{O}$, $\mathrm{MeOH}$, stirred in rt (3h); (v) $\mathrm{ArCHO}$, EtOH, reflux (6h) $\mathrm{R}: \mathrm{H}, 4-\mathrm{CH}_{3}, 2-\mathrm{Cl}, 4-\mathrm{Cl}, 4-\mathrm{Br}, 2-\mathrm{OCH}_{3}, 4-\mathrm{N}\left(\mathrm{CH}_{3}\right)_{2}, 3-\mathrm{Br}, 2-\mathrm{F}, 4-\mathrm{F}, 4-\mathrm{OCH}_{3}, 2-\mathrm{CH}_{3}$

Scheme 1. Synthetic pathway for the production of 6-(4-(2-fluorophenyl) piperazine-1-yl)-3(2H)pyridazinone-2-acetyl-2-(substituted/non-substituted benzal)hydrazone derivatives (T1-T12).

Table 1. Molecular structures, yields, melting points, molecular weights, and molecular formulae of $\mathrm{T} 1-12$.

\begin{tabular}{cccccc}
\hline & & & \\
& & & & \\
& & & & \\
Compound No. & $\mathbf{R}$ & Yield (\%) & $\mathbf{P}$ & Molecular Formula \\
\hline T1 & $\mathrm{H}$ & 79.90 & $226-228$ & 434.48 & $\mathrm{C}_{23} \mathrm{H}_{23} \mathrm{FN}_{6} \mathrm{O}_{2}$ \\
T2 & $4-\mathrm{CH}_{3}$ & 78.15 & $198-200$ & 448.49 & $\mathrm{C}_{24} \mathrm{H}_{25} \mathrm{FN}_{6} \mathrm{O}_{2}$ \\
T3 & $2-\mathrm{Cl}$ & 73.19 & $203-205$ & 468.91 & $\mathrm{C}_{23} \mathrm{H}_{22} \mathrm{ClFN}_{6} \mathrm{O}_{2}$ \\
T4 & $4-\mathrm{Cl}$ & 91.21 & $192-194$ & 468.91 & $\mathrm{C}_{23} \mathrm{H}_{22} \mathrm{ClFN}_{6} \mathrm{O}_{2}$ \\
T5 & $4-\mathrm{Br}$ & 85.69 & $209-211$ & 513.36 & $\mathrm{C}_{23} \mathrm{H}_{22} \mathrm{BrFN}_{6} \mathrm{O}_{2}$ \\
T6 & $2-\mathrm{CH} \mathrm{H}_{3} \mathrm{O}$ & 77.45 & $239-241$ & 464.49 & $\mathrm{C}_{24} \mathrm{H}_{25} \mathrm{FN}_{6} \mathrm{O}_{3}$ \\
T7 & $4-\mathrm{N}\left(\mathrm{CH}_{3}\right)_{2}$ & 68.77 & $237-239$ & 477.53 & $\mathrm{C}_{25} \mathrm{H}_{28} \mathrm{FN}_{7} \mathrm{O}_{2}$ \\
T8 & $3-\mathrm{Br}$ & 90.08 & $207-208$ & 513.36 & $\mathrm{C}_{23} \mathrm{H}_{22} \mathrm{BrFN}_{6} \mathrm{O}_{2}$ \\
T9 & $2-\mathrm{F}$ & 88.36 & $225-226$ & 452.47 & $\mathrm{C}_{23} \mathrm{H}_{22} \mathrm{~F}_{2} \mathrm{~N}_{6} \mathrm{O}_{2}$ \\
T10 & $4-\mathrm{F}$ & 57.70 & $178-180$ & 452.47 & $\mathrm{C}_{23} \mathrm{H}_{22} \mathrm{~F}_{2} \mathrm{~N}_{6} \mathrm{O}_{2}$ \\
T11 & $4-\mathrm{OCH}_{3}$ & 75.32 & $148-150$ & 464.49 & $\mathrm{C}_{24} \mathrm{H}_{25} \mathrm{FN}_{6} \mathrm{O}_{3}$ \\
T12 & $2-\mathrm{CH}_{3}$ & 72.21 & $244-245$ & 448.49 & $\mathrm{C}_{24} \mathrm{H}_{25} \mathrm{FN}_{6} \mathrm{O}_{2}$ \\
\hline
\end{tabular}

It was observed that these compounds were in two stereoisomeric forms by interpretation of NMR spectra. For example, T10 existed as two stereoisomeric forms in ${ }^{1} \mathrm{H}-\mathrm{NMR}$ spectrum (Figure 1A), indicating the resonance of methylene attached to the carbonyl group at 5.30 and $4.87 \mathrm{ppm}(2 \mathrm{H}$; $\mathrm{s} ; \mathrm{CH}_{2} \mathrm{CO}$ ) and two pairs of singlet (one pair at 8.0 and $8.4 \mathrm{ppm}$ and another one at 9.5 and $10.6 \mathrm{ppm}$ ) (Figure 1B). In addition, the carbons of pyridazinone $C^{6}$, pyridazinone $C^{4}$, and 2-fluorophenyl $C^{5}$ were double in ${ }^{13} \mathrm{C}$-NMR spectrum at low $\mathrm{MHz}$ (Figure 1C). These pairs of signals clearly show that these compounds exist in two stereoisomeric forms, as other isomers described previously [32,33]. 
(A)

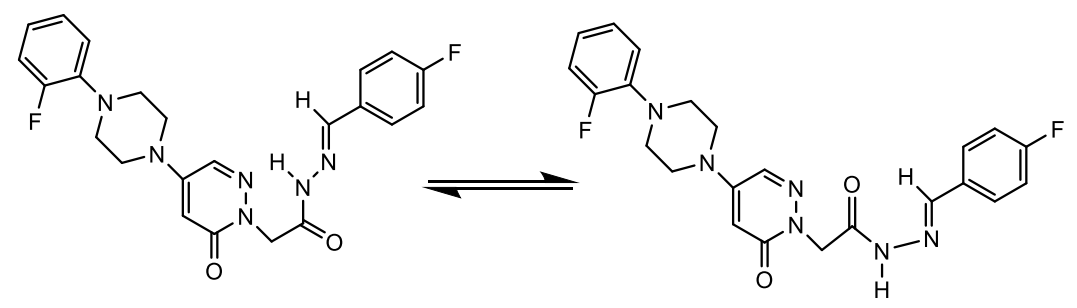

(B)

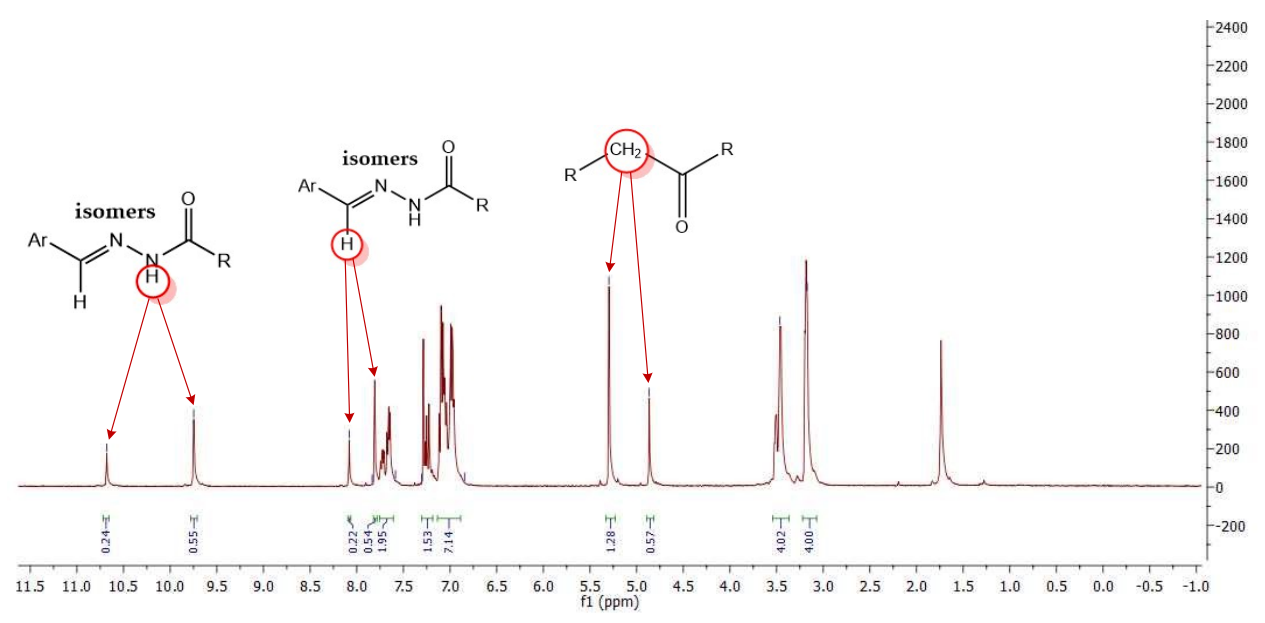

(C)

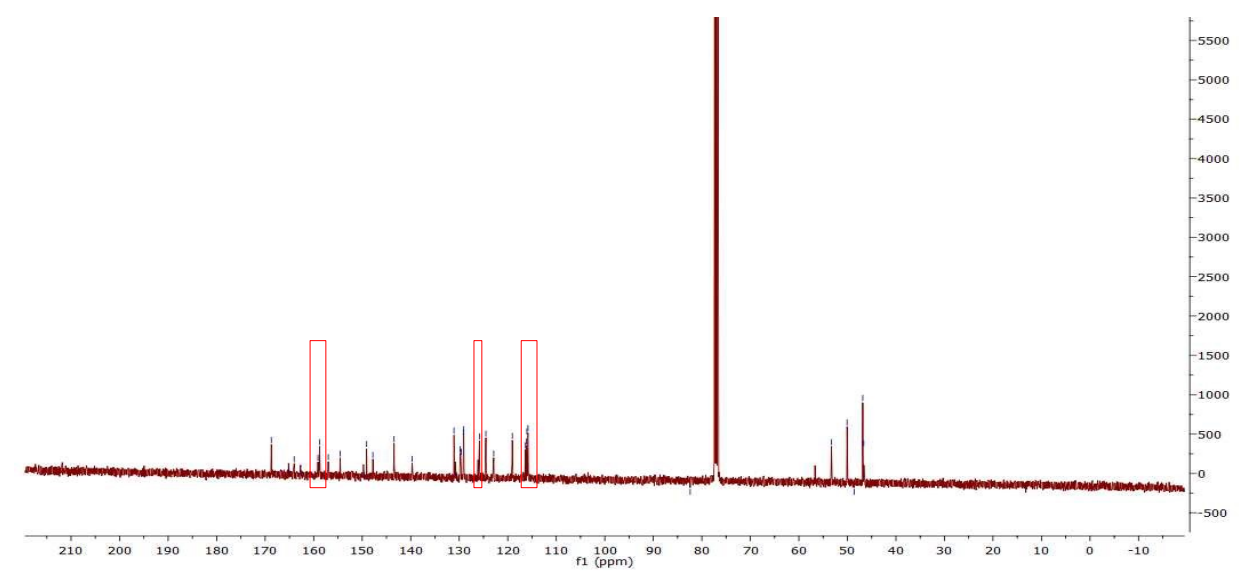

Figure 1. Structures of two conformational isomers (A), and ${ }^{1} \mathrm{H}-\mathrm{NMR}(\mathbf{B})$ and ${ }^{13} \mathrm{C}-\mathrm{NMR}(\mathbf{C})$ spectra of T10.

\subsection{MAO Inhibitory Activities}

Of the 12 derivatives, six potently inhibited MAO-B with residual activities of $<50 \%$ at $1.0 \mu \mathrm{M}$ (Table 2). T6 most potently inhibited MAO-B, with an $\mathrm{IC}_{50}$ value of $0.013 \mu \mathrm{M}$, and was followed by T3 and T4 $\left(\mathrm{IC}_{50}=0.039\right.$ and $0.099 \mu \mathrm{M}$, respectively). T2, T12, and T9 also potently inhibited MAO-B $\left(\mathrm{IC}_{50}=0.10,0.15\right.$, and $0.20 \mu \mathrm{M}$, respectively). Bromine at the meta position (T6) increased MAO-B inhibitory activity more so than at the para position (T7). Regarding substituents at the para position, MAO-B inhibitory activities increased in the order: $-\mathrm{Cl}(\mathrm{T} 3)>-\mathrm{N}\left(\mathrm{CH}_{3}\right)_{2}(\mathrm{~T} 12)>-\mathrm{OCH}_{3}(\mathrm{~T} 9)>-\mathrm{Br}(\mathrm{T} 7)$ 
$>-\mathrm{F}(\mathrm{T} 5)>-\mathrm{CH}_{3}(\mathrm{T11})>-\mathrm{H}(\mathrm{T1})$. In addition, $\mathrm{T} 6$ efficiently inhibited MAO-A with an $\mathrm{IC}_{50}$ value of $1.57 \mu \mathrm{M}$, followed by $\mathrm{T} 3\left(\mathrm{IC}_{50}=4.19 \mu \mathrm{M}\right)($ Table 2$)$, and $\mathrm{T} 6$ also had the highest selectivity index (SI) value (120.8) for MAO-B, followed by T3 (SI = 107.4).

Table 2. Inhibitions of recombinant human MAO-A and MAO-B by $\mathrm{T} 1$ to $\mathrm{T} 12^{\mathrm{a}}$.

\begin{tabular}{|c|c|c|c|c|c|}
\hline \multirow{3}{*}{ Compounds } & \multicolumn{2}{|c|}{ Residual Activity (\%) } & \multicolumn{2}{|c|}{$\mathrm{IC}_{50}(\mu \mathrm{M})$} & \multirow{3}{*}{$\mathrm{SI}^{\mathbf{b}}$} \\
\hline & MAO-A & MAO-B & \multirow{2}{*}{ MAO-A } & \multirow{2}{*}{ MAO-B } & \\
\hline & $(10 \mu \mathrm{M})$ & $(1.0 \mu \mathrm{M})$ & & & \\
\hline T1 & $96.6 \pm 1.20$ & $99.4 \pm 0.85$ & - & $7.68 \pm 0.14$ & - \\
\hline T2 & $24.6 \pm 2.86$ & $4.22 \pm 0.85$ & $4.29 \pm 0.12$ & $0.10 \pm 0.035$ & 42.9 \\
\hline T3 & $24.6 \pm 0.97$ & $3.01 \pm 0.85$ & $4.19 \pm 0.27$ & $0.039 \pm 0.0028$ & 107.4 \\
\hline $\mathrm{T} 4$ & $75.2 \pm 4.70$ & $6.00 \pm 0.94$ & - & $0.099 \pm 0.0069$ & - \\
\hline T5 & $84.0 \pm 0.68$ & $54.0 \pm 2.83$ & - & $1.68 \pm 0.11$ & - \\
\hline T6 & $20.7 \pm 0.62$ & $-15.3 \pm 0.94$ & $1.57 \pm 0.80$ & $0.013 \pm 0.0016$ & 120.8 \\
\hline T7 & $25.4 \pm 6.92$ & $57.8 \pm 9.58$ & $4.43 \pm 0.29$ & $0.87 \pm 0.056$ & - \\
\hline T8 & $73.3 \pm 2.86$ & $67.2 \pm 9.58$ & - & $2.67 \pm 0.051$ & - \\
\hline T9 & $35.2 \pm 0.56$ & $2.60 \pm 0.74$ & $6.76 \pm 0.46$ & $0.20 \pm 0.0017$ & 33.8 \\
\hline T10 & $33.7 \pm 4.70$ & $95.3 \pm 6.70$ & $7.35 \pm 0.059$ & $35.3 \pm 0.39$ & 0.21 \\
\hline T11 & $70.4 \pm 8.50$ & $61.1 \pm 2.98$ & - & $6.86 \pm 0.37$ & - \\
\hline T12 & $61.8 \pm 1.65$ & $17.9 \pm 5.95$ & - & $0.15 \pm 0.021$ & - \\
\hline Toloxatone & & & $1.08 \pm 0.025$ & - & \\
\hline Lazabemide & & & - & $0.14 \pm 0.011$ & \\
\hline Clorgyline & & & $0.0070 \pm 0.00070$ & - & \\
\hline Pargyline & & & - & $0.030 \pm 0.00083$ & \\
\hline
\end{tabular}

${ }^{a}$ Results are expressed as the means \pm standard errors of duplicate or triplicate experiments; ${ }^{b}$ Selectivity index (SI) values shown are expressed as IC50 of MAO-A/IC50 of MAO-B; IC50 values for reference compounds were determined after preincubating them for $30 \mathrm{~min}$ with MAO-A or MAO-B.

The presence of different substituents on the phenyl hydrazone ring did not appreciably impact MAO selectivity, whereas the introduction of halogens, methoxy, methyl, or dimethylamino groups reduced MAO-B inhibition versus non-substituted hydrazone. The lead compounds T6 and T3, which had methoxy or chlorine groups at the ortho position of the phenyl system, were 11 and 3 times more potent, respectively, than the reference reversible MAO-B inhibitor lazabemide. Furthermore, T6 was twice as potent as the reference irreversible MAO-B inhibitor pargyline. Shifting methoxy group from the ortho to the para position of the phenyl ring (T11) dramatically reduced MAO-B inhibition $\left(\mathrm{IC}_{50}=6.86 \pm 0.37 \mu \mathrm{M}\right)$ and shifting chlorine from the ortho to the para $(\mathrm{T} 4)$ reduced MAO-B inhibition. These observations indicate that ortho is preferred over para in terms of MAO-B inhibition. Interestingly, recent studies have reported that chlorine and methoxy groups have considerable impacts on MAO-B inhibition [34,35].

\subsection{Kinetics of $M A O-B$ Inhibitions}

Lineweaver-Burk plots and secondary plots obtained for MAO-B inhibition showed that T3 and T6 were competitive inhibitors (Figure 2A,C), with $K_{i}$ values of $0.014 \pm 0.0014$ and $0.0071 \pm 0.0033 \mu \mathrm{M}$, respectively (Figure 2B,D). These results suggest that $\mathbf{T} 3$ and $\mathbf{T} 6$ are competitive inhibitors of MAO-B.

\subsection{Reversibility Studies}

Reversibility studies were performed using a dialysis-based method. Dialysis recovered MAO-B inhibition by T3 from $22.2 \%\left(A_{U}\right)$ to $79.4 \%\left(A_{D}\right)$ (Figure 3). T6 was also recovered from $36.9 \%\left(A_{U}\right)$ to $79.0 \%\left(A_{D}\right)$ (Figure 3$)$. These degrees of recovery were similar to that observed for lazabemide (the reversible reference MAO-B inhibitor) (from 36.9\% to 83.0\%). However, inhibition by pargyline (irreversible MAO-B inhibitor) was not recovered. These experiments showed that inhibitions of 
MAO-B by $\mathbf{T} 3$ and $\mathbf{T} 6$ were recovered by dialysis to the reversible reference level, thus showing that T3 and T6 reversibly inhibit MAO-B.

(A)

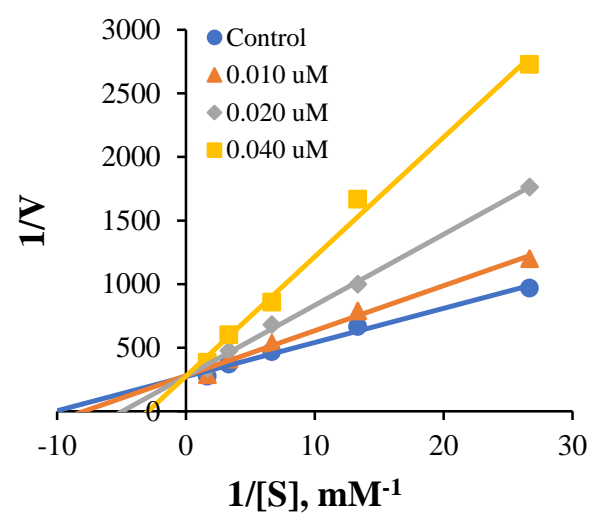

(C)

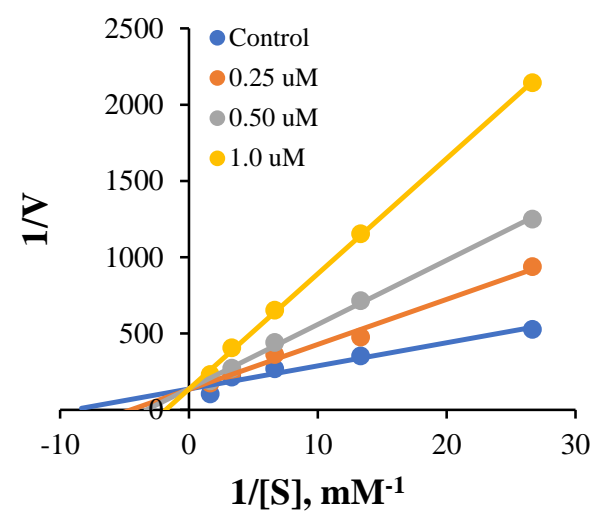

(B)

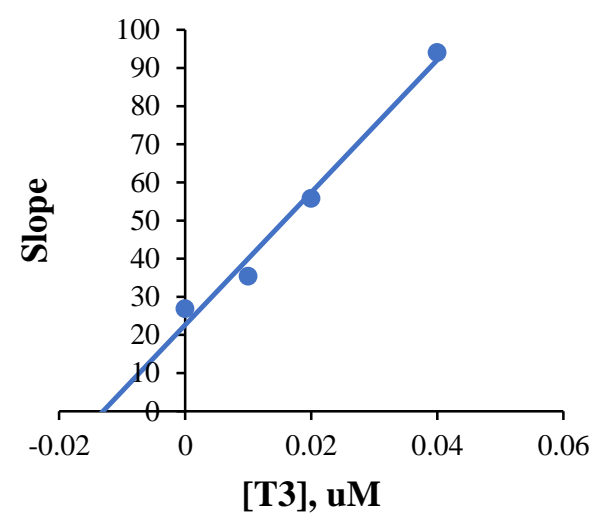

(D)

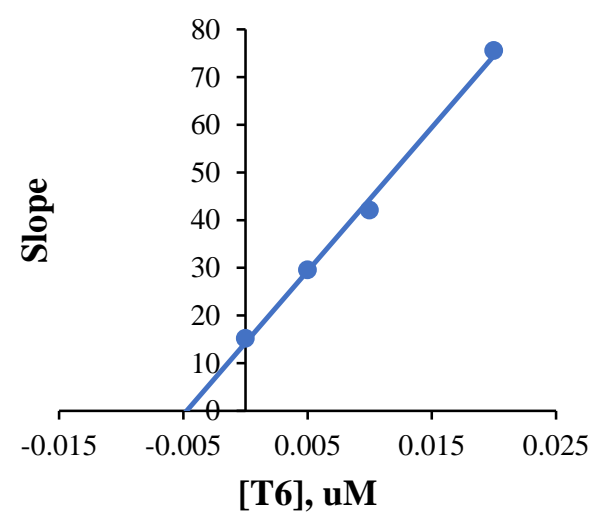

Figure 2. Lineweaver-Burk plots for MAO-B inhibition by $\mathbf{T} 3$ or $\mathbf{T 6}(\mathrm{A}, \mathrm{C})$, and respective secondary plots $(\mathbf{B}, \mathbf{D})$ of slopes vs. inhibitor concentrations.

Undialyzed

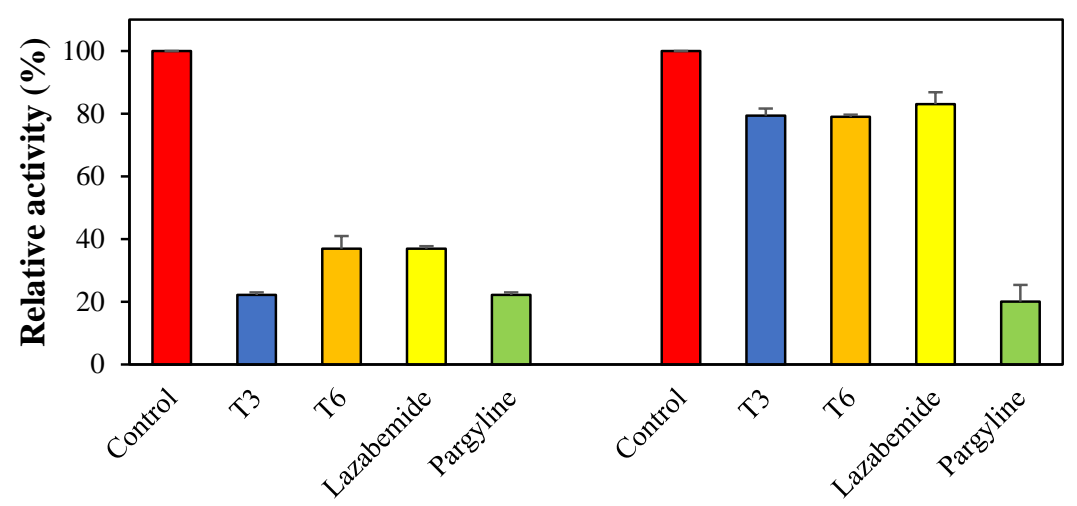

Figure 3. Recoveries of MAO-B inhibitions by $\mathrm{T} 3$ and $\mathrm{T} 6$ by dialysis.

\subsection{Cytotoxic Effects of the Active Pyridazinone Derivatives}

The cytotoxic effects of T3 and T6 were investigated using L929 cells (a healthy fibroblast cell line). T3 caused complete cell death at 50 and $100 \mu \mathrm{M}$ ), but no significant death at 1, 10, or $20 \mu \mathrm{M}$ (Figure 4). 
T6 did not have a cytotoxic effect at any dose (Figure 4). The $\mathrm{IC}_{50}$ values of $\mathbf{T} 3$ and $\mathbf{T} 6$ were 27.05 and $120.6 \mu \mathrm{M}$, respectively. These results suggested that T6 is a more appropriate drug candidate [30].

(A)

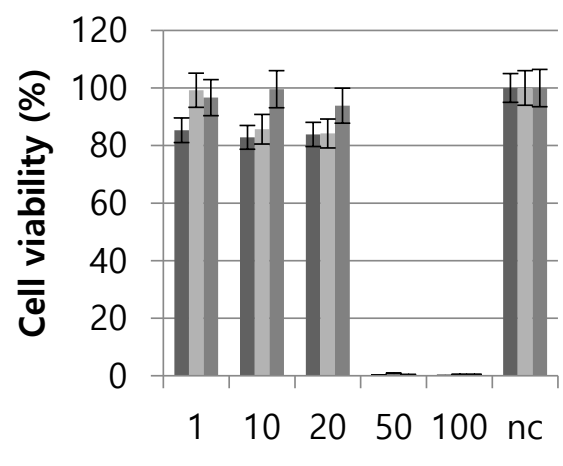

Concentration $(\mu \mathrm{M})$
(B)

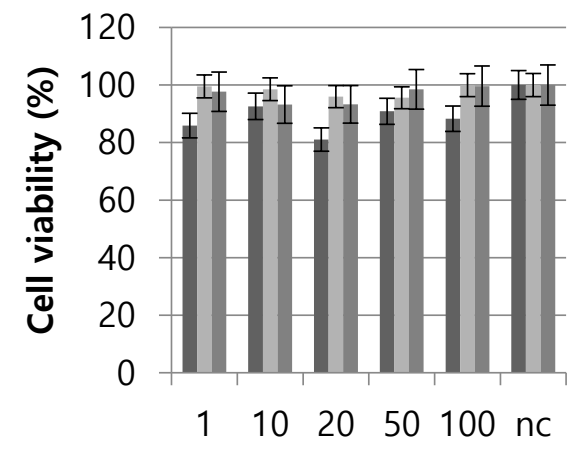

Concentration $(\mu \mathrm{M})$

Figure 4. L929 cell viabilities after treatments with T3 (A) or T6 (B). nc, normal control. The experiments were performed with three sets at each concentration.

\subsection{Molecular Docking Studies}

Docking simulations were used to investigate molecular interactions and binding modes of T3 or T6 with MAO-A or MAO-B. Simulations docking scores are provided in Table 3. The ortho-fluorine phenyl rings of T3 and T6 interacted with F352 of MAO-A by $\pi-\pi$ contact and by hydrophobic interaction with Y444, Y407, and the FAD of MAO-A (Figure 5). Moreover, the pyridazinone ring of T6 was well oriented towards F208 of MAO-A, and established another hydrophobic interaction. The ortho positioned fluorine on the phenyl ring of $\mathbf{T} 3$ or $\mathbf{T} 6$ faced a hydrophobic cage consisting of FAD, Y435, and $\mathrm{Y} 398$ of MAO-B, similar to MAO-A binding mode (Figure 6). Pyridazinone rings participated in hydrophobic interactions with the MAO-B selective residue Y326, and the hydrazone moieties of T3 and T6 formed hydrogen bonds with the E84 side-chain and the T201 backbone of MAO-B.

Table 3. Docking score values for T3 and T6 interactions with MAO-A or MAO-B.

\begin{tabular}{ccc}
\hline \multirow{2}{*}{ Compounds } & \multicolumn{2}{c}{ Docking Score (kcal/mol) } \\
\cline { 2 - 3 } & MAO-A & MAO-B \\
\hline T3 & -8.20 & -9.45 \\
T6 & -8.43 & -9.56 \\
\hline
\end{tabular}

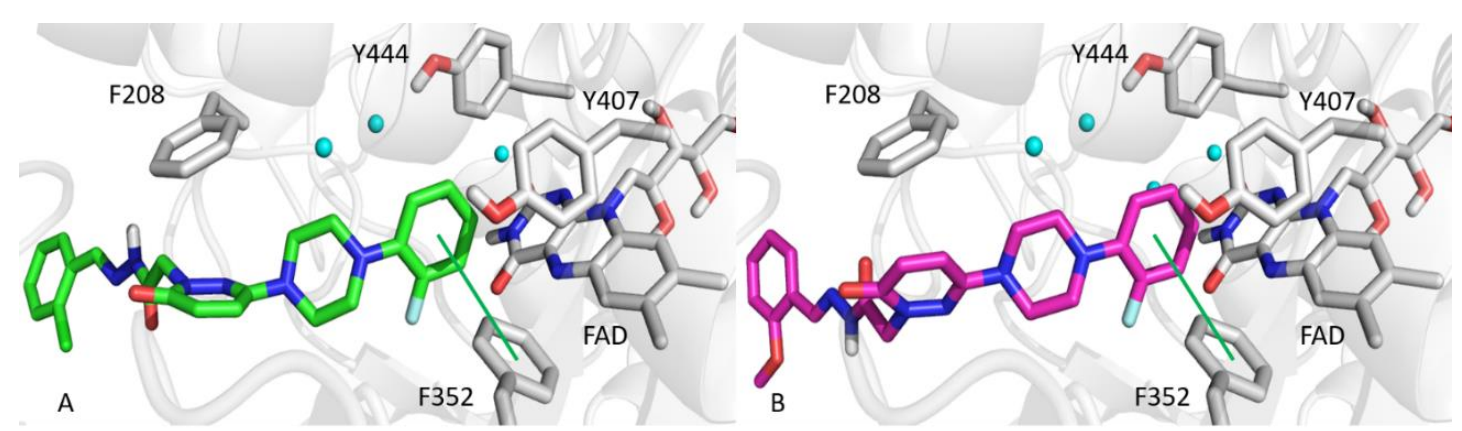

Figure 5. Top scored poses of T3 (A, green sticks) and T6 (B, magenta sticks) towards MAO-A. Green lines show $\pi-\pi$ interactions. Water molecules are rendered as cyan spheres. 


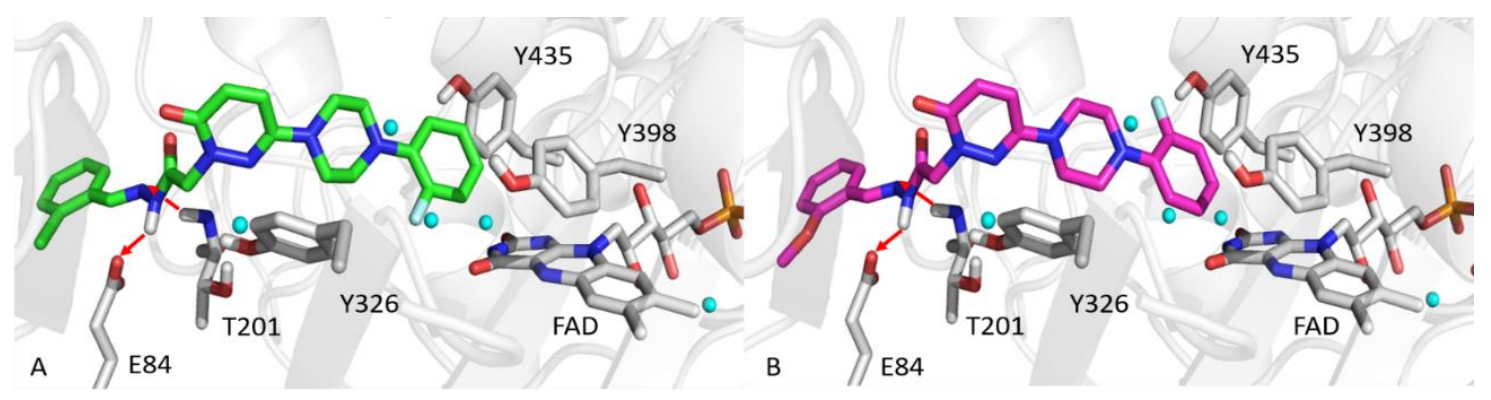

Figure 6. Top scored poses of T3 (A, green sticks) and T6 (B, magenta sticks) towards MAO-B. Red arrows indicate hydrogen bonds. Water molecules are rendered as cyan spheres.

Computational studies of T3 or T6 interactions with MAO-A or MAO-B provided satisfactory explanations for the experimental biological data obtained. Docking scores of T3 and T6 agreed with $\mathrm{IC}_{50}$ experimental values, which indicated $\mathbf{T} 6$ is better than T3. Regarding binding modes, the ortho-fluorine phenyl rings of T3 and T6 face the hydrophobic cages of MAO-A and MAO-B. Interestingly, the main difference between MAO-A and MAO-B interactions centers on the presence of two hydrogen bonds between the hydrazone moieties of T3 and T6 and E84 and T201 of MAO-B, due to no hydrogen bond with their corresponding sites V93 and V210 in MAO-A, thus supporting that $\mathbf{T} 3$ and $\mathbf{T} 6$ are selective MAO-B inhibitors.

\subsection{ADME Prediction}

The physicochemical parameters and likenesses of T3 and T6 were further investigated by BOILED-Egg construction and using the SwissADME online platform. These online programs determine whether compounds are suitable for oral administration based on the bioavailability radar panel containing physicochemical properties such as flexibility, insolubility, lipophilicity, saturation, size, and polarity, and provide rapid appraisals of the drug-likenesses of drug candidates. The BOILED-Egg constructions of T3 and T6 predicted that both are well absorbed in the GI tract but in outside of blood-brain barrier (BBB) permeation range (Figure 7). T3 and T6 were shown to lie within the pink regions (optimal ranges) (Figure 8). Bioavailability radar predicted both compounds had acceptable pharmacokinetics and satisfied drug-likeness rules. These results suggest that $\mathbf{T} 3$ and $\mathbf{T} 6$ should be considered potential drug candidates.
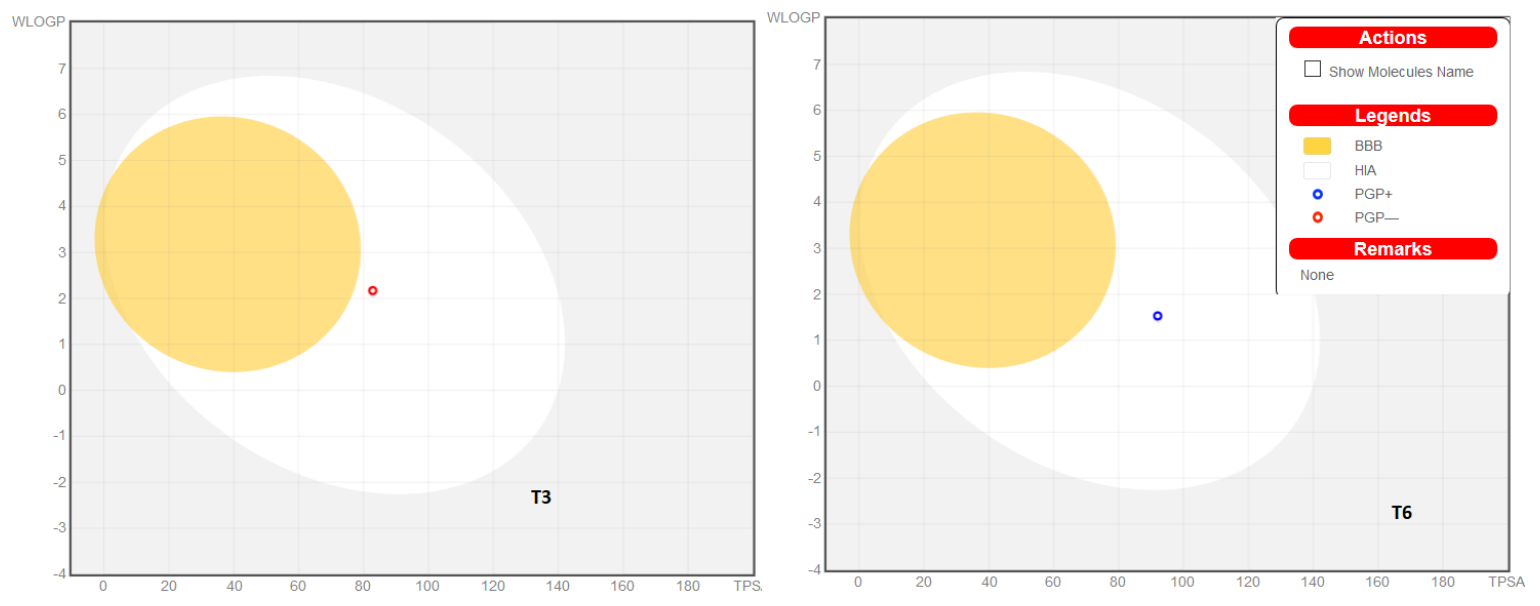

Figure 7. The BOILED-Egg construction of T3 and T6. 


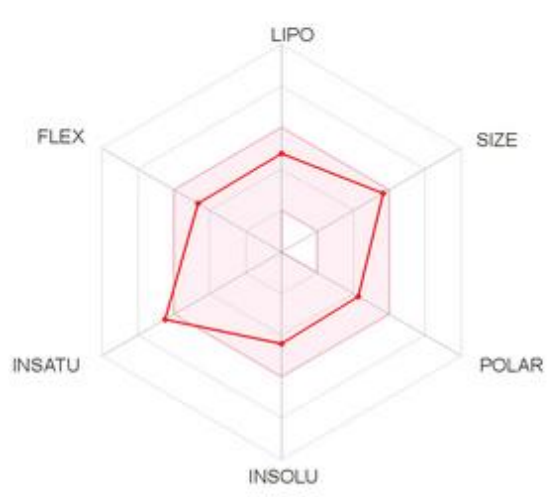

A

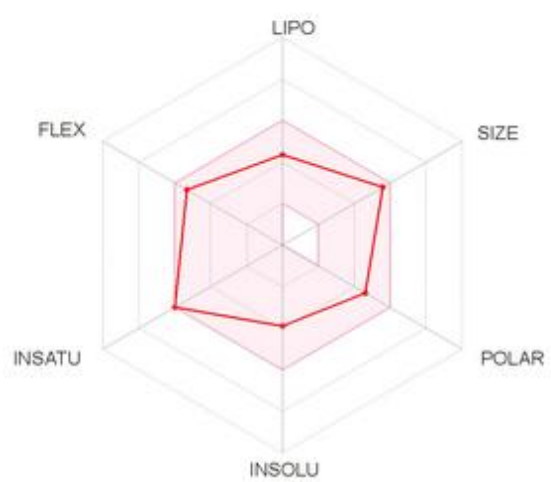

B

Figure 8. The bioavailability radar of T3 (A) and T6 (B).

\section{Materials and Methods}

\subsection{Chemical Studies}

All chemicals used in this study were purchased from Aldrich, Fluka AG, or E. Merck. 3-Chloro-6-substituted pyridazines, 3-chloro-6-(4-(2-fluorophenyl)piperazine-1-yl)pyridazine, 6-(4-(2fluorophenyl)piperazine-1-yl)-3(2H)-pyridazinone, ethyl 6-(4-(2-fluorophenyl)piperazine-1-yl)-3(2H)pyridazinone-2-yl acetate, and 6-(4-(2-fluorophenyl) piperazine-1-yl)-3(2H)-pyridazinone-2-yl acetohydrazide were synthesized as previously described [20-24]. The purities of these compounds were checked by TLC using Merck Kieselgel $F_{254}$ plates. Melting points were determined using an Electrothermal 9200 (Cole-Parmer Instrument Co. Vernon Hills, IL, USA), and IR spectra were recorded on a Perkin Elmer Spectrometer using the ATR technique. ${ }^{1} \mathrm{H}-\mathrm{NMR}$ and ${ }^{13} \mathrm{C}-\mathrm{NMR}$ spectra were recorded on a Brucker Avonce Ultrashield FT-NMR spectrometer in DMSO at 600 and $75 \mathrm{MHz}$, respectively. Mass spectra (HRMS) were obtained using a combined Waters Acquity Ultra Performance Liquid Chromatography Micromass and an LCT Premier XE UPLC/MS TOFF spectrophotometer (Waters Corp, Milford, MA, USA) in ESI+ and ESI- modes.

\subsection{Synthesis of Intermediates}

\subsubsection{Synthesis of 3-chloro-6-[4-(2-fluorophenyl)piperazine-1-yl]pyridazine (1)}

A solution containing $0.01 \mathrm{~mol}$ of 3,6-dichloropyridazine and $0.01 \mathrm{~mol}$ of (2-fluorophenyl) piperazine in $15 \mathrm{~mL}$ of ethanol was stirred under reflux at $120^{\circ} \mathrm{C}$ for $6 \mathrm{~h}$ with the cooler adjusted to $15^{\circ} \mathrm{C}$ as previously described [36]. The reaction mix was poured into ice water, and the precipitate obtained by filtration was purified by crystallization from ethanol. Melting points of non-original compounds were in accord with previously reported values [36].

\subsubsection{Synthesis of 6-(4-(2-fluorophenyl)piperazine-1-yl)-3(2H)-pyridazinone (2)}

A solution of $0.05 \mathrm{~mol}$ of 3-chloro-6-[4-(2-fluorophenyl)piperazine-1-yl]pyridazine in $30 \mathrm{~mL}$ glacial acetic acid was refluxed for $6 \mathrm{~h}$. The acetic acid was then removed under reduced pressure, and the residue obtained was dissolved in water and extracted with chloroform. The organic phase was dried over sodium sulfate and evaporated under reduced pressure, and the residue was purified by recrystallization from ethanol. Melting points of non-original compounds were in accord with previously reported values [36]. 
3.2.3. Synthesis of ethyl 6-(4-(2-fluorophenyl)piperazine-1-yl)-3(2H)-pyridazinone-2-yl-acetate (3)

A mixture of 0.01 mol 6-(4-(2-fluorophenyl)piperazine-1-yl)-3(2H)-pyridazinone, 0.02 mol ethyl bromoacetate, and $0.02 \mathrm{~mol}$ potassium carbonate in acetone $(40 \mathrm{~mL})$ was refluxed overnight. After the mixture had cooled, organic salts were filtered off, the solvent was evaporated, and the residue was purified by recrystallization from $n$-hexane to give the esters. Melting points of non-original compounds were in accord with previously reported values [36].

3.2.4. Synthesis of 6-(4-(2-fluorophenyl)piperazine-1-yl)-3(2H)-pyridazinone-2-yl-acetohydrazide (4)

Hydrazine hydrate $(99 \%, 3 \mathrm{~mL}$ ) was added to the solution of 0.01 mol ethyl 6-(4-(2-fluorophenyl) piperazine-1-yl)-3(2H)-pyridazinone-2-yl-acetate in $25 \mathrm{~mL}$ methanol and stirred for $3 \mathrm{~h}$ at room temperature. The precipitate obtained was filtered off, washed with water, dried, and recrystallized from ethanol. Melting points of non-original compounds were in accord with previously reported values [36].

\subsubsection{General Procedure for the Synthesis of T1-T12}

A solution containing $0.01 \mathrm{~mol}$ 6-(4-(2-fluorophenyl)piperazine-1-yl)-3(2H)-pyridazinone-2-ylacetohydrazide and $0.01 \mathrm{~mol}$ substituted/non-substituted benzaldehyde was stirred in ethanol $(15 \mathrm{~mL})$, refluxed for $6 \mathrm{~h}$, and poured into ice water. The precipitate was filtered, dried, and crystallized from methanol:water $(8: 2, v / v)$ [34]. All spectral data of the five new compounds (T8-T12) were in accord with assigned structures.

3.2.6. 6-[4-(2-Fluorophenyl)piperazine-1-yl]-3(2H)-pyridazinone-2-acetyl-2-(3-bromobenzal) hydrazon (T8)

White crystals (methanol/water); yield 90.08\%; m.p. $207-208{ }^{\circ} \mathrm{C} ;{ }^{1} \mathrm{H}-\mathrm{NMR}$ (DMSO- $d_{6}, 300 \mathrm{MHz}$ ): $\delta 3.18\left(4 \mathrm{H} ; \mathrm{t} ; \mathrm{CH}_{2} \mathrm{~N} ; \mathrm{b}+\mathrm{b}^{\prime}\right), 3.45\left(4 \mathrm{H} ; \mathrm{t} ; \mathrm{CH}_{2} \mathrm{~N} ; \mathrm{a}+\mathrm{a}^{\prime}\right), 5.31\left(2 \mathrm{H} ; \mathrm{s} ; \mathrm{CH}_{2} \mathrm{CO}\right), 6.96(1 \mathrm{H} ; \mathrm{d} ; J=4.14 \mathrm{~Hz}$, pyridazinone $\left.\mathrm{H}^{5}\right), 6.97-7.87\left(9 \mathrm{H} ; \mathrm{m}\right.$; phenyl protons, pyridazinone $\left.\mathrm{H}^{4}\right), 8.58(1 \mathrm{H} ; \mathrm{s} ;-\mathrm{N}=\mathrm{CH}-)$ and 10.80 $(1 \mathrm{H} ; \mathrm{s} ;-\mathrm{NH}-\mathrm{N}) .{ }^{13} \mathrm{C}-\mathrm{NMR}$ (DMSO- $\left.d_{6}, 300 \mathrm{MHz}\right), \delta 46.82\left(2 \mathrm{C}, \mathrm{CH}_{2}-\mathrm{N} ; \mathrm{b}+\mathrm{b}^{\prime}\right), 50.05\left(2 \mathrm{C}, \mathrm{CH}_{2}-\mathrm{N} ; \mathrm{a}+\mathrm{a}^{\prime}\right)$, $53.14\left(1 \mathrm{C} ;-\mathrm{N}-\underline{C H}_{2}-\mathrm{C}=\mathrm{O}\right), 115.13(1 \mathrm{C} ;=\mathrm{CH}), 119.10$ (1C; pyridazinone $\mathrm{C}^{5}$ ), 122.96 (1C; 2-fluorophenyl $\left.C^{4}\right), 124.55\left(1 \mathrm{C}\right.$; 3-bromophenyl $\left.C^{5}\right), 125.90$ (1C; 2-fluorophenyl $\left.C^{5}\right), 126.05$ (1C; 3-bromophenyl $\left.C^{2}\right), 129.72\left(1 C\right.$; 3-bromophenyl $\left.C^{6}\right), 130.26\left(1 C\right.$; pyridazinone $\left.C^{4}\right), 131.08\left(1 C\right.$; 2-fluorophenyl $\left.C^{6}\right)$, 134.22 (1C; 3-bromophenyl $\left.C^{3}\right), 142.99$ (1C; 2-fluorophenyl $\left.C^{3}\right), 147.39$ (1C; 3-bromophenyl $\left.C^{1}\right), 149.13$ (1C; 2-fluorophenyl $\left.C^{1}\right)$, $154.40\left(1 C\right.$; 3-bromophenyl $\left.C^{4}\right), 156.56\left(1 C\right.$; pyridazinone $\left.C^{6}\right), 158.53(1 C$; 2-fluorophenyl $\mathrm{C}^{2}$ ), $161.02\left(1 \mathrm{C} ; \mathrm{CH}_{2}-\mathrm{N}-\underline{\mathrm{C}}=\mathrm{O}\right), 168.75\left(1 \mathrm{C}\right.$; pyridazinone $\left.\mathrm{C}^{3}\right) ; \mathrm{C}_{23} \mathrm{H}_{22} \mathrm{BrFN}_{6} \mathrm{O}_{2} \mathrm{MS}$ (ESI+) calculated: 513.3714 , found: $m / e$ 513.10526 $\left(\mathrm{M}^{+} ; 100.0 \%\right)$.

3.2.7. 6-[4-(2-Fluorophenyl)piperazine-1-yl]-3(2H)-pyridazinone-2-acetyl-2-(2-fluorobenzal) hydrazon (T9)

White crystals (methanol/water); yield 88.36\%; m.p. $225-226{ }^{\circ} \mathrm{C} ;{ }^{1} \mathrm{H}-\mathrm{NMR}$ (DMSO- $d_{6}, 300 \mathrm{MHz}$ ):

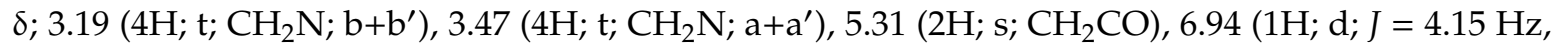
pyridazinone $\left.\mathrm{H}^{5}\right), 6.95-7.49\left(9 \mathrm{H} ; \mathrm{m}\right.$; phenyl protons, pyridazinone $\left.\mathrm{H}^{4}\right), 8.96(1 \mathrm{H} ; \mathrm{s} ;-\mathrm{N}=\mathrm{CH}-)$ and 10.69 $(1 \mathrm{H} ; \mathrm{s} ;-\mathrm{NH}-\mathrm{N}) .{ }^{13} \mathrm{C}-\mathrm{NMR}\left(\mathrm{DMSO}-d_{6}, 300 \mathrm{MHz}\right), 46.63\left(2 \mathrm{C}, \mathrm{CH}_{2} \mathrm{~N} ; \mathrm{b}+\mathrm{b}^{\prime}\right), 50.07\left(2 \mathrm{C}, \mathrm{CH}_{2} \mathrm{~N} ; \mathrm{a}+\mathrm{a}^{\prime}\right)$, $53.29\left(1 \mathrm{C} ;-\mathrm{N}-\mathrm{CH}_{2}-\mathrm{C}=\mathrm{O}\right), 115.83(1 \mathrm{C} ;=\mathrm{CH}), 116.14\left(1 \mathrm{C}\right.$; pyridazinone $\left.\mathrm{C}^{5}\right), 119.06$ (1C; 2-fluorophenyl $\left.C^{6^{\prime}}\right), 122.90\left(1 C ; 2\right.$-fluorophenyl $\left.C^{5^{\prime}}\right), 124.51\left(1 C ; 2\right.$-fluorophenyl $\left.C^{4^{\prime}}\right), 125.84$ (1C; 2-fluorophenyl $\left.C^{5}\right), 129.07\left(1 C\right.$; 2-fluorophenyl $\left.C^{4}\right), 129.15$ (1C; pyridazinone $\left.C^{4}\right), 129.62\left(1 C ; 2\right.$-fluorophenyl $\left.C^{6}\right)$, 129.70 (1C; 2-fluorophenyl $\left.C^{3}\right), 129.78$ (1C; 2-fluorophenyl $\left.C^{3^{\prime}}\right), 131.09$ (1C; 2-fluorophenyl $\left.C^{1}\right), 143.43$ (1C; 2-fluorophenyl $\left.C^{1^{\prime}}\right), 147.80$ (1C; 2-fluorophenyl $\left.C^{2^{\prime}}\right), 149.09$ (1C; pyridazinone $\left.C^{6}\right), 154.54$ (1C; 2-fluorophenyl $\left.\mathrm{C}^{2}\right), 158.79\left(1 \mathrm{C} ; \mathrm{CH}_{2}-\mathrm{N}-\mathrm{C}=\mathrm{O}\right)$ and 168.73 (1C; pyridazinone $\left.\mathrm{C}^{3}\right) ; \mathrm{C}_{23} \mathrm{H}_{22} \mathrm{~F}_{2} \mathrm{~N}_{6} \mathrm{O}_{2} \mathrm{MS}$ (ESI+) calculated: 452.47 , found: $453.18594 \mathrm{~m} / \mathrm{e}\left(\mathrm{M}^{+} ; 100.0 \%\right)$. 
3.2.8. 6-[4-(2-Fluorophenyl)piperazine-1-yl]-3(2H)-pyridazinone-2-acetyl-2-(4-florobenzal) hydrazon (T10)

White crystals (methanol/water); yield 57.70\%; m.p. $178-180{ }^{\circ} \mathrm{C} ;{ }^{1} \mathrm{H}-\mathrm{NMR}$ (DMSO- $d_{6}, 300 \mathrm{MHz}$ ): $\delta ; 3.17\left(4 \mathrm{H} ; \mathrm{t} ; \mathrm{CH}_{2} \mathrm{~N} ; \mathrm{b}+\mathrm{b}^{\prime}\right), 3.46\left(4 \mathrm{H} ; \mathrm{t} ; \mathrm{CH}_{2} \mathrm{~N} ; \mathrm{a}+\mathrm{a}^{\prime}\right), 5.30\left(2 \mathrm{H} ; \mathrm{s} ; \mathrm{CH}_{2} \mathrm{CO}\right), 6.84(1 \mathrm{H} ; \mathrm{d} ; J=4.15 \mathrm{~Hz}$, pyridazinone $\left.\mathrm{H}^{5}\right), 6.85-7.83\left(9 \mathrm{H} ; \mathrm{m}\right.$; phenyl protons, pyridazinone $\left.\mathrm{H}^{4}\right), 8.08(1 \mathrm{H} ; \mathrm{s} ;-\mathrm{N}=\mathrm{CH}-)$ and 10.68 $(1 \mathrm{H} ; \mathrm{s} ;-\mathrm{NH}-\mathrm{N}) .{ }^{13} \mathrm{C}-\mathrm{NMR}\left(\mathrm{DMSO}-d_{6}, 300 \mathrm{MHz}\right), 46.84\left(2 \mathrm{C}, \mathrm{CH}_{2} \mathrm{~N} ; \mathrm{b}+\mathrm{b}^{\prime}\right), 50.07\left(2 \mathrm{C}, \mathrm{CH}_{2} \mathrm{~N} ; \mathrm{a}+\mathrm{a}^{\prime}\right)$, $53.29\left(1 \mathrm{C} ;-\mathrm{N}-\underline{C H}_{2}-\mathrm{C}=\mathrm{O}\right), 115.83(1 \mathrm{C} ;=\mathrm{CH}), 116.05$ (1C; pyridazinone $\left.\mathrm{C}^{5}\right), 116.35$ (1C; 4-fluorophenyl $\left.C^{6}\right), 122.90\left(1 C ; 4\right.$-fluorophenyl $\left.C^{5}\right), 124.51\left(1 C\right.$; 4-fluorophenyl $\left.C^{4}\right), 125.84$ (1C; 2-fluorophenyl $\left.C^{5}\right), 129.07\left(1 C\right.$; 2-fluorophenyl $\left.C^{4}\right), 129.62\left(1 C\right.$; pyridazinone $\left.C^{4}\right), 129.70\left(1 C\right.$; 2-fluorophenyl $\left.C^{6}\right)$, 130.68 (1C; 2-fluorophenyl $\left.C^{3}\right), 139.71$ (1C; 4-fluorophenyl $\left.C^{3}\right), 147.80$ (1C; 2-fluorophenyl $\left.C^{1}\right), 149.09$ (1C; 4-fluorophenyl $\left.C^{1}\right), 154.54$ (1C; 4-fluorophenyl $\left.C^{2}\right)$, 158.79 (1C; pyridazinone $\left.C^{6}\right), 162.52(1 C$; 2-fluorophenyl $\left.\mathrm{C}^{2}\right), 165.16\left(1 \mathrm{C} ; \mathrm{CH}_{2}-\mathrm{N}-\underline{\mathrm{C}}=\mathrm{O}\right.$ ) and $168.73\left(1 \mathrm{C}\right.$; pyridazinone $\left.\mathrm{C}^{3}\right) ; \mathrm{C}_{23} \mathrm{H}_{22} \mathrm{~F}_{2} \mathrm{~N}_{6} \mathrm{O}_{2} \mathrm{MS}$ (ESI+) calculated: 452.47 , found: $453.18583 \mathrm{~m} / \mathrm{e}\left(\mathrm{M}^{+} ; 100.0 \%\right)$.

3.2.9. 6-[4-(2-Fluorophenyl)piperazine-1-yl]-3(2H)-pyridazinone-2-acetyl-2-(4-methoxybenzal) hydrazon (T11)

White crystals (methanol/water); yield 75.32\%; m.p. $148-150{ }^{\circ} \mathrm{C} .{ }^{1} \mathrm{H}-\mathrm{NMR}$ (DMSO- $d_{6}, 300 \mathrm{MHz}$ ): $\delta 3.17\left(4 \mathrm{H} ; \mathrm{t} ; \mathrm{CH}_{2} \mathrm{~N} ; \mathrm{b}+\mathrm{b}^{\prime}\right), 3.45\left(4 \mathrm{H} ; \mathrm{t} ; \mathrm{CH}_{2} \mathrm{~N} ; \mathrm{a}+\mathrm{a}^{\prime}\right), 3.85\left(3 \mathrm{H} ; \mathrm{s} ; \mathrm{CH}_{3} \mathrm{O}\right), 5.30\left(2 \mathrm{H} ; \mathrm{s} ; \mathrm{CH}_{2} \mathrm{CO}\right), 6.88$ $\left(1 \mathrm{H} ; \mathrm{d} ; J=4.15 \mathrm{~Hz}\right.$, pyridazinone $\left.\mathrm{H}^{5}\right), 6.89-7.79\left(9 \mathrm{H}\right.$; m; phenyl protons, pyridazinone $\left.\mathrm{H}^{4}\right), 8.64(1 \mathrm{H}$; $\mathrm{s} ;-\mathrm{N}=\mathrm{CH}-)$ and $10.55(1 \mathrm{H} ; \mathrm{s} ;-\mathrm{NH}-\mathrm{N}) .{ }^{13} \mathrm{C}-\mathrm{NMR}\left(\mathrm{DMSO}-d_{6}, 300 \mathrm{MHz}\right), 46.83\left(2 \mathrm{C}, \mathrm{CH}_{2} \mathrm{~N} ; \mathrm{b}+\mathrm{b}^{\prime}\right), 50.07(2 \mathrm{C}$, $\left.\mathrm{CH}_{2} \mathrm{~N} ; \mathrm{a}+\mathrm{a}^{\prime}\right), 53.03\left(1 \mathrm{C} ;-\mathrm{N}-\mathrm{CH}_{2}-\mathrm{C}=\mathrm{O}\right), 55.38\left(1 \mathrm{C} ;-\mathrm{OCH}_{3}\right), 114.07(1 \mathrm{C} ;=\mathrm{CH}), 116.12(1 \mathrm{C}$; pyridazinone $\left.C^{5}\right), 119.07\left(1 C\right.$; 4-methoxyphenyl $\left.C^{6}\right), 124.50$ (1C; 4-methoxyphenyl $\left.C^{5}\right), 125.77(1 C$; 4-methoxyphenyl $\left.C^{4}\right), 126.30\left(1 C\right.$; 2-fluorophenyl $\left.C^{5}\right), 128.82\left(1 C ;\right.$ 2-fluorophenyl $\left.C^{4}\right), 129.43$ (1C; pyridazinone $\left.C^{4}\right)$, 130.14 (1C; 2-fluorophenyl $\left.C^{6}\right), 131.10$ (1C; 2-fluorophenyl $\left.C^{3}\right), 139.63$ (1C; 4-methoxyphenyl $C^{3}$ ), 144.42 (1C; 2-fluorophenyl $\left.C^{1}\right), 149.04$ (1C; 4-methoxyphenyl $\left.C^{1}\right), 154.39\left(1 C ; 4\right.$-methoxyphenyl $\left.C^{2}\right)$, $156.83\left(1 \mathrm{C}\right.$; pyridazinone $\left.\mathrm{C}^{6}\right), 158.82\left(1 \mathrm{C}\right.$; 2-fluorophenyl $\left.\mathrm{C}^{2}\right), 161.35\left(1 \mathrm{C} ; \mathrm{CH}_{2}-\mathrm{N}-\mathrm{C}=\mathrm{O}\right)$ and $168.56(1 \mathrm{C}$; pyridazinone $\mathrm{C}^{3}$ ); $\mathrm{C}_{24} \mathrm{H}_{25} \mathrm{FN}_{6} \mathrm{O}_{3} \mathrm{MS}$ (ESI+) calculated: 464.49 , found: $465.20506 \mathrm{~m} / \mathrm{e}\left(\mathrm{M}^{+} ; 100.0 \%\right)$.

3.2.10. 6-[4-(2-Fluorophenyl)piperazine-1-yl]-3(2H)-pyridazinone-2-acetyl-2-(2-methylbenzal) hydrazon (T12)

White crystals (methanol/water); yield 72.21\%; m.p. $244-245{ }^{\circ} \mathrm{C} ;{ }^{1} \mathrm{H}-\mathrm{NMR}$ (DMSO- $d_{6}, 300 \mathrm{MHz}$ ): $\delta 2.50\left(3 \mathrm{H} ; \mathrm{s} ;-\mathrm{CH}_{3}\right), 3.17\left(4 \mathrm{H} ; \mathrm{t} ; \mathrm{CH}_{2} \mathrm{~N} ; \mathrm{b}+\mathrm{b}^{\prime}\right), 3.45\left(4 \mathrm{H} ; \mathrm{t} ; \mathrm{CH}_{2} \mathrm{~N} ; \mathrm{a}+\mathrm{a}^{\prime}\right), 5.30\left(2 \mathrm{H} ; \mathrm{s} ; \mathrm{CH}_{2} \mathrm{CO}\right), 6.92(1 \mathrm{H} ;$ $\mathrm{d} ; J=4.19 \mathrm{~Hz}$, pyridazinone $\left.\mathrm{H}^{5}\right), 6.92-7.77\left(9 \mathrm{H}\right.$; m; phenyl protons, pyridazinone $\left.\mathrm{H}^{4}\right), 8.37(1 \mathrm{H}$; $\mathrm{s}$; -N=CH-) and $10.58(1 \mathrm{H} ; \mathrm{s} ;-\mathrm{NH}-\mathrm{N}) .{ }^{13} \mathrm{C}-\mathrm{NMR}$ (DMSO- $\left.d_{6}, 300 \mathrm{MHz}\right), \delta 20.16\left(1 \mathrm{C} ;-\mathrm{CH}_{3}\right), 46.69\left(2 \mathrm{C} ; \mathrm{CH}_{2}-\mathrm{N}\right.$; $\left.\mathrm{b}+\mathrm{b}^{\prime}\right), 50.10\left(2 \mathrm{C}, \mathrm{CH}_{2}-\mathrm{N} ; \mathrm{a}+\mathrm{a}^{\prime}\right), 53.36\left(1 \mathrm{C} ;-\mathrm{N}^{-\mathrm{CH}_{2}}-\mathrm{C}=\mathrm{O}\right), 116.13(1 \mathrm{C} ;=\mathrm{CH}), 119.07(1 \mathrm{C} ;$ pyridazinone $\left.C^{5}\right), 122.87$ (1C; 4-methylphenyl $\left.C^{6}\right), 124.54$ (1C; 2-methylphenyl $\left.C^{2}\right), 125.78$ (1C; 2-methylphenyl $\left.C^{3}\right), 126.24\left(1 C\right.$; 4-methylphenyl $\left.C^{5}\right), 127.47\left(1 C ; 4\right.$-methylphenyl $\left.C^{4}\right), 129.96\left(1 C\right.$; pyridazinone $\left.C^{4}\right)$, 130.85 (1C; 2-fluorophenyl $C^{3}$ ), 131.48 (1C; 2-fluorophenyl $C^{4}$ ), 137.13 (1C; 2-fluorophenyl $C^{5}$ ), 143.70 $\left(1 C\right.$; 2-methylphenyl $\left.C^{1}\right), 147.49$ (1C; 2-fluorophenyl $\left.C^{6}\right), 149.71\left(1 C\right.$; 2-fluorophenyl $\left.C^{1}\right), 156.98(1 C$; 2-fluorophenyl $\mathrm{C}^{2}$ ), 158.81 (1C; pyridazinone $\left.\mathrm{C}^{6}\right) 163.96\left(1 \mathrm{C} ; \mathrm{CH}_{2}-\mathrm{N}-\mathrm{C}=\mathrm{O}\right.$ ) and 168.57 (1C; pyridazinone $\left.\mathrm{C}^{3}\right) ; \mathrm{C}_{24} \mathrm{H}_{25} \mathrm{FN}_{6} \mathrm{O}_{2} \mathrm{MS}$ (ESI+) calculated: 448.49 , found: $449.21034 \mathrm{~m} / \mathrm{e}\left(\mathrm{M}^{+} ; 100.0 \%\right)$.

\subsection{Enzyme Assays}

Recombinant human MAO-A and MAO-B inhibitory activities of were continuously assayed as described previously [37], using kynuramine $(0.06 \mathrm{mM})$ and benzylamine $(0.3 \mathrm{mM})$, respectively. Substrate concentrations were $1.5 \times$ and $2.3 \times K_{m}$, respectively, and their $K_{m}$ values were $0.041 \mathrm{mM}$ and $0.13 \mathrm{mM}$, respectively. MAO-A and MAO-B inhibitory activities were measured after preincubating enzymes and inhibitors for $15 \mathrm{~min}$. Enzymes and chemicals were obtained from Sigma-Aldrich (St. Louis, MO, USA). 


\subsection{Enzyme Inhibitions and Kinetics}

The inhibitory activities of the twelve compounds against MAO-A and MAO-B were first investigated at an inhibitor concentration of $10 \mu \mathrm{M}$. For the compounds showing residual activities of $<50 \%, \mathrm{IC}_{50}$ values for MAO-A and MAO-B inhibitions were determined. Kinetic experiments were carried out at five substrate and three inhibitor concentrations [38].

\subsection{Analysis of Inhibitor Reversibilities}

The reversibilities of T3 and T6 inhibitions were investigated by dialysis after preincubating them with MAO-B for $30 \mathrm{~min}$, as previously described [39]. The concentrations used were T3 $0.080 \mu \mathrm{M}$, T6 $0.020 \mu \mathrm{M}$, lazabemide (reference reversible MAO-B inhibitor) $0.30 \mu \mathrm{M}$, and pargyline (reference irreversible MAO-B inhibitor) $0.060 \mu \mathrm{M}$. Reversibilities were determined using the relative activities of undialyzed $\left(\mathrm{A}_{\mathrm{U}}\right)$ and dialyzed $\left(\mathrm{A}_{\mathrm{D}}\right)$ samples [40].

\subsection{Cytotoxicity}

An MTS (5-(3-carboxymethoxyphenyl)-2-(4,5-dimethyl-thiazolyl)-3-(4-sulfophenyl)) tetrazolium assay was used to evaluate the cytotoxic activities of T3 and T6 by measuring formazan absorbance. MTS is converted to formazan by mitochondria in metabolically active cells via NAD(P)H-dependent dehydrogenase enzymes. L929 cells (a mouse fibroblast cell line) were used to evaluate the cytotoxicities. Briefly, cells $\left(5 \times 10^{4}\right.$ cells/well) were seeded into 96-well plates in DMEM containing $10 \%$ fetal bovine serum and 1\% penicillin/streptomycin, and incubated for $24 \mathrm{~h}$. After supernatants were removed, the cells were treated with the compounds dissolved in DMSO (at 1, 10, 20, 50, or $100 \mu \mathrm{M}$ ) in triplicate for $48 \mathrm{~h}$ at $37^{\circ} \mathrm{C}$ in a $5 \% \mathrm{CO}_{2}$ atmosphere. MTS reagent (Uptima, Interchim, Montluçon, France) was then added to each well and incubated for $3 \mathrm{~h}$. Absorbances were measured at $490 \mathrm{~nm}$ using a microplate reader (BioTek, Winooski, VT, USA), and cell viabilities were calculated as percentage of untreated controls [30].

\subsection{Molecular Docking Studies}

T3 and T6 were docked using X-ray solved structures of MAO-A and MAO-B obtained from the Protein Data Bank (PDB) by retrieving entries 2Z5X and 2V5Z, respectively [41,42]. Protein targets were prepared using the Protein Preparation Wizard Schrödinger Suite 2018-4 (New York, NY, USA) for refining and optimizing crystal structures after correcting for protonation states and adding missing hydrogen atoms $[43,44]$. Nine water molecules within MAO-A and eight water molecules within MAO-B were not deleted for docking simulations, as was previously performed [45]. To generate all possible tautomers and protonation states at physiological $\mathrm{pH}, \mathbf{T} 3$ and $\mathbf{T} 6$ were treated using the LigPrep tool [46]. The obtained files were used for docking simulations by employing Grid-based Ligand Docking with Energetics (GLIDE) [47]. Enclosing boxes were automatically centered on the related cognate ligands, T3 and T6. The default force Field OPLS_20058 and the standard precision (SP) docking protocol with default settings were employed for the in silico analyses. To confirm the validity of docking studies, re-docking simulations were performed on T3 and T6 at their binding sites. The cognate ligands are flagged as HRM and SAG for MAO-A and MAO-B, respectively, and moved back to the original positions with Root Mean Square Deviations (RMSD) accounting for all heavy atoms equal to $0.760 \AA$ and $0.395 \AA$ for HRM and SAG, respectively [48].

\subsection{ADME Prediction}

ADME parameters were predicted in silico to determine a range of physical-chemical properties, lipophilicity, water solubility, and pharmacokinetic data, using the login-free website http://www. swissadme.ch/ [49]. 


\section{Conclusions}

The present work describes the synthesis of twelve pyridazinones (T1-T12) containing the 2-fluorophenyl substituted piperazine moiety. All synthesized compounds were evaluated for MAO-A and MAO-B inhibitory activities. Most of the compounds were selective MAO-B inhibitors, and T3 and T6 were found to be selective, competitive, and reversible MAO-B inhibitors. T3 and T6 potently and reversibly inhibited MAO-B in the sub-micromolar range, and were relatively non-toxic to healthy fibroblasts. We concluded that T3 and T6 offer new developmental leads for the treatment of neurodegenerative disorders.

Supplementary Materials: ${ }^{1} \mathrm{H}$ - and ${ }^{13} \mathrm{C}-\mathrm{NMR}$ spectral data are available in the Supplementary Materials.

Author Contributions: Conceptualization: Z.Ö., B.M. and H.K.; biological activity: J.M.O.; kinetics: J.M.O.; docking analysis: N.G., O.N.; synthesis: M.C., Z.Ö.; data curation: B.M., J.M.O.; writing—original draft preparation: B.M., S.E.B., M.U., M.A.A., A.M.; writing-review and editing: B.M. and K.H.; supervision: H.K.; funding acquisition: H.K. All authors have read and agreed to the published version of the manuscript.

Funding: This research was supported by the National Research Foundation of Korea (NRF) grant funded by the Republic of Korea government (NRF-2019R1A2C1088967) (to H.K.).

Conflicts of Interest: The authors have no conflict of interest to declare.

\section{References}

1. Harilal, S.; Jose, J.; Parambi, D.G.T.; Kumar, R.; Mathew, G.E.; Uddin, M.S.; Kim, H.; Mathew, B. Advancements in nanotherapeutics for Alzheimer's disease: Current perspectives. J. Pharm. Pharmacol. 2019, 71, 1370-1383. [CrossRef] [PubMed]

2. Geldenhuys, W.J.; Darvesh, A.S. Pharmacotherapy of Alzheimer's disease: Current and future trends. Expert. Rev. Neurother. 2015, 5, 3-5. [CrossRef] [PubMed]

3. Chiu, P.Y.; Wei, C.Y. Donepezil in the one-year treatment of dementia with Lewy bodies and Alzheimer's disease. J. Neurol. Sci. 2017, 81, 22. [CrossRef]

4. Mathew, B.; Parambi, D.G.T.; Mathew, G.E.; Uddin, M.S.; Inasu, S.T.; Kim, H.; Marathakam, A.; Unnikrishnan, M.K.; Carradori, S. Emerging therapeutic potentials of dual-acting MAO and AChE inhibitors in Alzheimer's and Parkinson's diseases. Arch. Pharm. 2019, 352, e1900177. [CrossRef] [PubMed]

5. Kim, D.; Baik, S.H.; Kang, S.; Cho, S.W.; Bae, J.; Cha, M.Y.; Sailor, M.J.; Jung, I.M.; Ahn, K.H. Close correlation of monoamine oxidase activity with progress of Alzheimer's disease in mice, observed by in vivo two-photon imaging. ACS Cent. Sci. 2016, 2, 967-975. [CrossRef] [PubMed]

6. Kumar, B.; Prakash, V.; Kumar, V. A perspective on monoamine oxidase enzyme as drug target: Challenges and opportunities. Curr. Drug Targets. 2017, 18, 87-97. [CrossRef] [PubMed]

7. Finberg, J.P.M.; Rabey, J.M. Inhibitors of MAO-A and MAO-B in psychiatry and neurology. Front. Pharmacol. 2016, 7, 340. [CrossRef]

8. Guglielmi, P.; Mathew, B.; Secci, D.; Carradori, S. Chalcones: Unearthing their therapeutic possibility as monoamine oxidase B inhibitors. Eur. J. Med. Chem. 2020, 112650. [CrossRef]

9. Carradori, S.; Silvestri, R. New frontiers in selective human MAO-B inhibitors. J. Med. Chem. 2015, 58, 6717-6732. [CrossRef]

10. Tripathi, R.K.P.; Ayyannan, S.R. Monoamine oxidase-B inhibitors as potential neurotherapeutic agents: An overview and update. Med. Res. Rev. 2019, 39, 1603-1706. [CrossRef]

11. Guglielmi, P.; Carradori, S.; Ammazzalorso, A.; Secci, D. Novel approaches to the discovery of selective human monoamine oxidase-B inhibitors: Is there room for improvement? Expert Opin. Drug Discov. 2019, 14, 995-1035. [CrossRef] [PubMed]

12. Kumar, B.; Sheetal, S.; Mantha, A.K.; Kumar, V. Recent developments on the structure-activity relationship studies of MAO inhibitors and their role in different neurological disorders. RSC Adv. 2016, 6, 42660-42683. [CrossRef]

13. Mathew, B.; Haridas, A.; Suresh, J.; Mathew, G.E.; Ucar, G.; Jayaprakash, V. Monoamine oxidase inhibitory actions of chalcones. A mini review. Cent. Nerv. Syst. Agents Med. Chem. 2016, 16, 120-136. [CrossRef] [PubMed] 
14. Choi, J.W.; Jang, B.K.; Cho, N.; Park, J.H.; Yeon, S.K.; Ju, E.J.; Lee, Y.S.; Han, G.; Pae, A.M.; Kim, D.J.; et al. Synthesis of a series of unsaturated ketone derivatives as selective and reversible monoamine oxidase inhibitors. Bioorg. Med. Chem. 2015, 23, 6486-6496. [CrossRef] [PubMed]

15. Mathew, B.; Mathew, G.E.; Petzer, J.P.; Petzer, A. Structural exploration of synthetic chromones as selective MAO-B inhibitors. A Mini Review. Comb. Chem. High Throughput Screen. 2017, 20, 522-532. [CrossRef] [PubMed]

16. Gaspar, A.; Silva, T.; Yáñez, M.; Viña, D.; Orallo, F.; Ortuso, F.; Uriarte, E.; Alcaro, S.; Borges, F. Chromone, a privileged scaffold for the development of monoamine oxidase inhibition. J. Med. Chem. 2011, 54, 5165-5173. [CrossRef]

17. Reis, J.; Cagide, F.; Chavarria, D.; Silva, T.B.; Fernandes, C.; Gaspar, A.; Uriarte, E.; Remiao, F.; Alcaro, S.; Ortuso, F.; et al. Discovery of new chemical entities of old targets. Insight on the lead optimization of chromones based monoamine oxidase B inhibitors. J. Med. Chem. 2016, 59, 5879-5893. [CrossRef]

18. Badavath, V.N.; Baysal, I.; Ucar, G.; Sinha, B.N.; Jayaprakash, V. Monoamine oxidase inhibitory activity of novel pyrazoline analogues: Curcumin based design and synthesis. ACS Med. Chem. Lett. 2016, 7, 56-61. [CrossRef]

19. Secci, D.; Bolasco, A.; Chimenti, P.; Carradori, S. The state of the art of pyrazole derivatives as monoamine oxidase inhibitors and antidepressant/anticonvulsant agents. Curr. Med. Chem. 2011, 18, 5114-5144. [CrossRef]

20. Mathew, B.; Suresh, J.; Anbazhagan, S.; Mathew, G.E. Pyrazoline. A promising scaffold for the inhibition of monoamine oxidase. Cent. Nerv. Syst. Agents Med. Chem. 2013, 13, 195-206. [CrossRef]

21. Matos, M.J.; Vina, D.; Vazquez-Rodriquez, S.; Uriarte, E.; Santana, L. Focusing on new monoamine oxidase inhibitors. Differently substituted coumarins as an interesting scaffold. Curr. Top. Med. Chem. 2012, 12, 2210-2233. [CrossRef] [PubMed]

22. Guglielmi, P.; Secci, D.; Petzer, A.; Bagetta, D.; Chimenti, P.; Rotondi, G.; Ferrante, C.; Recinella, L.; Leone, S.; Alcaro, S.; et al. Benzo[b]tiophen-3-ol derivatives as effective inhibitors of human monoamine oxidase: Design, synthesis, and biological activity. J. Enzym. Inhib. Med. Chem. 2019, 34, 1511-1525. [CrossRef] [PubMed]

23. Oh, J.M.; Rangarajan, T.M.; Chaudhary, R.; Singh, R.P.; Singh, M.; Singh, R.P.; Tondo, A.R.; Gambacorta, N.; Nicolotti, O.; Mathew, B.; et al. Novel class of chalcone oxime ethers as potent monoamine oxidase-B and acetylcholinesterase inhibitors. Molecules 2020, 25, 2356. [CrossRef] [PubMed]

24. Maliyakkal, N.; Eom, B.H.; Heo, J.H.; Almoyad, M.A.A.; Parambi, D.G.T.; Gambacorta, N.; Nicolotti, O.; Beeran, A.A.; Kim, H.; Mathew, B. A new potent and selective monoamine oxidase-B inhibitor with extended conjugation in chalcone framework. 1-[4-(morpholin-4-yl)phenyl]-5-phenylpenta-2,4-dien-1-one. Chem. Med. Chem. 2020, 15, 1629-1633. [CrossRef] [PubMed]

25. Hagenow, J.; Hagenow, S.; Grau, K.; Khanfar, M.; Hefke, L.; Proschak, E.; Stark, H. Reversible small molecule inhibitors of MAO A and MAO B with anilide motifs. Drug Des. Dev. Ther. 2020, 14, 371-393. [CrossRef] [PubMed]

26. Kavully, F.S.; Oh, J.M.; Dev, S.; Kaipakasseri, S.; Palakkathondi, A.; Vengamthodi, A.; Azeez, R.F.A.; Tondo, A.R.; Nicolotti, O.; Kim, H.; et al. Design of enamides as new selective monoamine oxidase-B inhibitors. J. Pharm. Pharmacol. 2020, 72, 916-926. [CrossRef]

27. Turan-Zitouni, G.; Hussein, W.; Saglık, B.N.; Tabbi, A.; Korkut, B. Design, synthesis and biological evaluation of novel N-pyridyl-hydrazone derivatives as potential monoamine oxidase (MAO) inhibitors. Molecules 2018, 23, 113-124. [CrossRef] [PubMed]

28. Dubey, S.; Bhosle, P.A. Pyridazinone: An important element of pharmacophore possessing broad spectrum of activity. Med. Chem. Res. 2015, 24, 3579-3598. [CrossRef]

29. Özdemir, Z.; Alagöz, M.A.; Uslu, H.; Karakurt, A.; Erikci, A.; Ucar, G.; Uysa, M. Synthesis, molecular modelling and biological activity of some pyridazinone derivatives as selective human monoamine oxidase-B inhibitors. Pharmacol. Rep. 2020, 72, 692-704. [CrossRef]

30. Özdemir, Z.; Başak-Türkmen, N.; Ayhan, İ.; Çiftçi, O.; Uysal, M. Synthesis of new 6-[4-(2-fluorophenylpiperazine -1-yl)]-3(2h)-pyridazinone-2-acethyl-2-(substitutedbenzal)hydrazine derivatives and evaluation of their cytotoxic effects in liver and colon cancer cell lines. Pharm. Chem. J. 2019, 52, 923-929. [CrossRef]

31. Özdemir, Z.; Utku, S.; Mathew, B.; Carradori, S.; Orlando, G.; Simone, S.D.; Alagöz, M.A.; Özçelik, A.B.; Uysal, M.; Claudio Ferrante, F. Synthesis and biological evaluation of new 3(2H)-pyridazinone derivatives as non-toxic anti-cancer compounds against colon carcinoma cells. J. Enzym. Inhib. Med. Chem. 2020, 35, 1100-1109. [CrossRef] [PubMed] 
32. Vergara, S.; Carda, M.; Agut, R.; Yepes, L.M.; Velez, I.D.; Robledo, S.M.; Galeano, W.C. Synthesis, antiprotozoal activity and cytotoxicity in U-937 macrophages of triclosan-hydrazone hybrids. Med. Chem. Res. 2017, 26, 3262-3273. [CrossRef]

33. Govindasami, T.; Pandey, A.; Palanivelu, N.; Pandey, A. Synthesis, Characterization and antibacterial activity of biologically important vanillin related hydrazone derivatives. Int. J. Org. Chem. 2011, 1, 71-77. [CrossRef]

34. Mathew, B.; Mathew, G.E.; Ucar, G.; Joy, M.; Nafna, E.K.; Suresh, J. Monoamine oxidase inhibitory activity of methoxy-substituted chalcones. Int. J. Biol. Macromol. 2017, 104, 1321-1329. [CrossRef] [PubMed]

35. Mathew, B.; Ucar, G.; Mathew, G.E.; Mathew, S.; Purapurath, P.K.; Moolayil, F.; Mohan, S.; Gupta, S.V. Monoamine oxidase inhibitory activity: Methyl- versus chloro-chalcone derivatives. Chem. Med. Chem. 2016, 11, 2649-2655. [CrossRef]

36. Özçelik, A.B.; Özdemir, Z.; Sari, S.; Utku, S.; Uysal, M. A new series of pyridazinone derivatives as cholinesterases inhibitors: Synthesis, in vitro activity and molecular modeling studies. Pharmacol. Rep. 2019, 71, 1253-1263. [CrossRef]

37. Mathew, B.; Baek, S.C.; Parambi, D.G.T.; Lee, J.P.; Joy, M.; Annie Rilda, P.R.; Randev, R.V.; Nithyamol, P.; Vijayan, V.; Inasu, S.T.; et al. Selected aryl thiosemicarbazones as a new class of multi-targeted monoamine oxidase inhibitors. Med. Chem. Comm. 2018, 9, 1871-1881. [CrossRef]

38. Lee, H.W.; Ryu, H.W.; Kang, M.G.; Park, D.; Oh, S.R.; Kim, H. Potent selective monoamine oxidase B inhibition by maackiain, a pterocarpan from the roots of Sophora flavescens. Bioorg. Med. Chem. Lett. 2016, 26, 4714-4719. [CrossRef]

39. Baek, S.C.; Lee, H.W.; Ryu, H.W.; Kang, M.G.; Park, D.; Kim, S.H.; Cho, M.L.; Oh, S.R.; Kim, H. Selective inhibition of monoamine oxidase A by hispidol. Bioorg. Med. Chem. Lett. 2018, 15, 584-588. [CrossRef]

40. Parambi, D.G.T.; Oh, J.M.; Baek, S.C.; Lee, J.P.; Tondo, A.R.; Nicolotti, O.; Kim, H.; Mathew, B. Design, synthesis and biological evaluation of oxygenated chalcones as potent and selective MAO-B inhibitors. Bioorg. Chem. 2019, 93, 103335. [CrossRef]

41. Son, S.Y.; Ma, J.; Kondou, Y.; Yoshimura, M.; Yamashita, E.; Tsukihara, T. Structure of human monoamine oxidase A at 2.2-A resolution: The control of opening the entry for substrates/inhibitors. Proc. Natl. Acad. Sci. USA 2008, 105, 5739-5744. [CrossRef] [PubMed]

42. Binda, C.; Wang, J.; Pisani, L.; Caccia, C.; Carotti, A.; Salvati, P.; Edmondson, D.E.; Mattevi, A. Structures of human monoamine oxidase B complexes with selective noncovalent inhibitors: Safinamide and coumarin analogs. J. Med. Chem. 2007, 50, 5848-5852. [CrossRef]

43. Schrödinger Release 2018-2. Prime; Schrödinger, LLC: New York, NY, USA, 2018.

44. Schrödinger Release 2018-2. Glide; Schrödinger, LLC: New York, NY, USA, 2018.

45. Mangiatordi, G.F.; Alberga, D.; Pisani, L.; Gadaleta, D.; Trisciuzzi, D.; Farina, R.; Carotti, A.; Lattanzi, G.; Catto, M.; Nicolotti, O. A rational approach to elucidate human monoamine oxidase molecular selectivity. Eur. J. Pharm. Sci. 2017, 101, 90-99. [CrossRef] [PubMed]

46. LigPrep; Schrödinger, LLC: New York, NY, USA, 2018.

47. Friesner, R.A.; Banks, J.L.; Murphy, R.B.; Halgren, T.A.; Klicic, J.J.; Mainz, D.T.; Repasky, M.P.; Knoll, E.H.; Shelley, M.; Perry, J.K.; et al. Glide: A new approach for rapid, accurate docking and scoring. 1. Method and assessment of docking accuracy. J. Med. Chem. 2004, 47, 1739-1749. [CrossRef] [PubMed]

48. Reeta; Baek, S.C.; Lee, J.P.; Rangarajan, T.M.; Ayushee; Singh, R.P.; Singh, M.; Mangiatordi, G.F.; Nicolotti, O.; Kim, H.; et al. Ethyl acetohydroxamate incorporated chalcones: Unveiling a novel class of chalcones for multitarget monoamine oxidase-B inhibitors against Alzheimer's disease. CNS Neurol. Disord. Drug Targets 2019, 8, 643-654. [CrossRef] [PubMed]

49. Daina, A.; Michielin, O.; Zoete, V. SwissADME: A free web tool to evaluate pharmacokinetics, drug-likeness and medicinal chemistry friendliness of small molecules. Sci. Rep. 2017, 7, 42717. [CrossRef] [PubMed]

Sample Availability: Samples of the compounds are available from the authors.

Publisher's Note: MDPI stays neutral with regard to jurisdictional claims in published maps and institutional affiliations.

(C) 2020 by the authors. Licensee MDPI, Basel, Switzerland. This article is an open access article distributed under the terms and conditions of the Creative Commons Attribution (CC BY) license (http://creativecommons.org/licenses/by/4.0/). 